\title{
QUEEN'S
UNIVERSITY
BELFAST
}

\section{The impact of interventions to promote physical activity in urban green space: A systematic review and recommendations for future research}

\author{
Hunter, R. F., Christian, H., Veitch, J., Astell-Burt, T., Hipp, J. A., \& Schipperijn, J. (2015). The impact of \\ interventions to promote physical activity in urban green space: A systematic review and recommendations for \\ future research. Social Science and Medicine, 124, 246-256. https://doi.org/10.1016/j.socscimed.2014.11.051
}

Published in:

Social Science and Medicine

Document Version:

Peer reviewed version

Queen's University Belfast - Research Portal:

Link to publication record in Queen's University Belfast Research Portal

Publisher rights

(c) 2014 Elsevier Ltd. This manuscript version is made available under the CC-BY-NC-ND 4.0 license http://creativecommons.org/licenses/by$\mathrm{nc}-\mathrm{nd} / 4.0 /$,which permits distribution and reproduction for non-commercial purposes, provided the author and source are cited.

\section{General rights}

Copyright for the publications made accessible via the Queen's University Belfast Research Portal is retained by the author(s) and / or other copyright owners and it is a condition of accessing these publications that users recognise and abide by the legal requirements associated with these rights.

\section{Take down policy}

The Research Portal is Queen's institutional repository that provides access to Queen's research output. Every effort has been made to ensure that content in the Research Portal does not infringe any person's rights, or applicable UK laws. If you discover content in the Research Portal that you believe breaches copyright or violates any law, please contact openaccess@qub.ac.uk. 


\section{The Impact of Interventions to Promote Physical Activity in Urban Green Space:}

\section{A Systematic Review and Recommendations for Future Research}

\section{Abstract}

Evidence is mounting on the association between the built environment and physical activity with a call for intervention research. A broader approach which recognizes the role of supportive environments that can make healthy choices easier is required. A systematic review was undertaken to assess the effectiveness of interventions to encourage physical activity in urban green space. Five databases were searched independently by two reviewers using search terms relating to 'physical activity', ‘urban green space' and 'intervention' in July 2014. Eligibility criteria included: (i) intervention to encourage physical activity in urban green space which involved either a physical change to the urban green space or a physical activity intervention to promote use of urban green space or a combination of both; and (ii) primary outcome of physical activity. Of the 2405 studies identified, 12 were included. There was some evidence (4/9 studies showed positive effect) to support built environment only interventions for encouraging use and increasing physical activity in urban green space. There was more promising evidence ( $3 / 3$ studies showed positive effect) to support physical activity programs or physical activity programs combined with a physical change to the built environment, for increasing urban green space use and physical activity of users. Recommendations for future research include the need for longer term follow-up postintervention, adequate control groups, sufficiently powered studies, and consideration of the social environment, which was identified as a significantly under-utilized resource in this area. Interventions that involve the use of PA programs combined with a physical change to the built environment are likely to have a positive effect on physical activity. Robust evaluations of such interventions are urgently required. The findings provide a platform to 
inform the design, implementation and evaluation of future urban green space and physical activity intervention research.

Keywords: Built environment; physical activity; behavior change; systematic review; interventions; social environment; public health 


\section{Introduction}

Prevalence of physical inactivity and its associated health conditions are rising, and the inexorable slide to a more inactive lifestyle has worrying implications for future levels of obesity, morbidity and mortality (Lee et al, 2012). A broader approach which recognizes the role of supportive environments that can make healthy choices easier is required. However, physical activity (PA) is a complex behavior that is often discouraged in modern built and social environments (Khan et al, 2011). Considerable evidence is mounting on the association between PA and the built environment in which an individual lives (O Ferdinand et al, 2012). Accordingly, the potential of the built environment as a determinant of PA, and its ability to influence community and population levels of PA is becoming more widely recognized (DoH, 2007; WHO, 2010).

In particular, urban green space (UGS) has an important contribution to make to public health with potential physical, psychological, social, economic and environmental benefits (BedimoRung, 2005; Bowler et al, 2010; Lee and Maheswaran, 2010; Lachowycz and Jones, 2011). UGS is defined as all publicly owned and publicly accessible open space with a high degree of cover by vegetation, e.g., parks, woodlands, nature areas, and other green space within the city boundary area (Schipperijn et al, 2013). Cross-sectional evidence highlights the association between UGS and PA. The availability and accessibility of UGS, particularly across the socio-economic spectrum, offers the opportunity for recreation and active travel for little or no cost to the individual. Physical activity has been shown to have positive associations with proximity, access, size and quality of UGS (Giles-Corti et al, 2005; Mowen et al, 2007; Kaczynski et al, 2011). Attributes of UGS that might stimulate and encourage PA include walking/cycling paths, wooded areas, open spaces, water features, lighting, pleasant views, bike racks, parking lots, and playgrounds (Schipperijn et al, 2013). However, to date 
much of the research in this area has been observational and shows that many UGS are underutilized (Floyd et al, 2008; Cohen et al, 2010; Floyd et al, 2011; Kaczynski et al, 2011).

Interventions specifically targeting use of UGS may assist with increasing PA behavior change at the community and population level. Urban Green Spaces receive significant investment for modifications and programming, particularly from local authorities. Examples include improving access to UGS, improving walking/cycle paths, and playground/park facilities in UGS. Interventions to specifically promote and encourage use of UGS or specific features of UGS include awareness, marketing and promotional campaigns, and PA programs in UGS. There is a need to identify if such investments are effective in increasing use of UGS and PA of UGS users, and subsequently determine how to make best use of UGS for public health. As with other aspects of built environment research, there has been a call for evidence of the effectiveness of environmental interventions to initiate and help maintain PA behavior change. Therefore, the aim of this study was to undertake a systematic review to assess the effectiveness of interventions to promote PA in UGS, including the development of new UGS.

\section{Methods}

\section{Search Strategy}

Five electronic databases (Medline, EMBASE, CINAHL, Sport DISCUS and PubMed) were searched for articles published up to July 2014, and reference lists of included studies were hand searched for further relevant papers. Keywords relating to 'physical activity', 'urban green space’ and 'intervention’ were searched (see Appendix I).

\section{Eligibility Criteria}


Studies were included if they met the following criteria:

(i) intervention to promote/encourage PA in UGS

(ii) primary outcome measure of PA levels, including subjective and objective measures of overall PA, or walking and cycling specific measure, or recreation or active travel domain specific measure

(iii) a control/comparator group

(iv) English language

(v) full-text available

UGS was defined as all publicly owned and publicly accessible open space with a high degree of cover by vegetation, e.g., parks, woodlands, nature areas, and other green space within the city boundary area (Schipperijn et al, 2013).

Physical activity interventions that involved the following were included:

(i) a physical change to the built environment including environmental improvements or creation of new environmental PA opportunities (e.g., new footpaths, improved playgrounds);

(ii) an intervention to specifically promote/encourage use of UGS or specific features of UGS (e.g., awareness campaigns, PA programs in UGS).

(iii) a combination of physical change to the built environment and a specific awareness/promotion program to encourage PA in UGS.

\section{Evidence Synthesis}

Studies were categorized according to the main approach of the intervention: 1) built environment only intervention; 2) PA promotion only intervention; 3) combination of built environment change and PA promotion intervention. Key characteristics and outcomes of the 
studies were extracted and tabulated including study design, country, target population, description of intervention and control/comparator group, outcome measures, duration of follow-up and summary of study findings. The review followed the PRISMA guidelines (Moher et al, 2009) and risk of bias was assessed using the Cochrane Risk of Bias tool (Higgins et al, 2011), performed independently by two reviewers. While intended for controlled trials, the majority of items are applicable to other study designs and allocate lower scores to studies employing study designs which introduce bias.

\section{Results}

Appendix II shows the results of the literature search. Briefly, 2405 studies were initially identified, 64 full-text articles screened, and 12 studies included in the review.

\section{Study Characteristics}

Table 1 presents a summary of the included studies. Eleven of the studies were natural experiments with the majority using a quasi-experiment, controlled pre-post design $(n=8)$, and one difference-in-difference design (Branas et al, 2011). Only one study employed a RCT design (Cohen et al, 2013). Studies were mainly implemented in the US ( $n=9)$, particularly in California ( $n=6)$, and the other studies took place in Australia $(n=3)$. A number of studies were set in areas where the majority of the population were of low Socio-Economic Position (SEP) and of ethnic minority groups (Cohen et al, 2009a; Tester and Baker, 2009; Fitzhugh et al, 2010; Cohen et al, 2012; Veitch et al, 2012; Bohn-Goldhaum et al, 2013; Cohen et al, 2014), which are typical of inner-city areas. Given the heterogeneity in target populations, interventions and outcome measures it was not appropriate to pool results in a meta-analysis. 
Appendix III presents the results of the risk of bias assessment described by study. Only one study had a low risk of bias (Cohen et al, 2013), which employed an RCT design, with five studies assessed as having a high risk of bias (Merom et al, 2003; Cohen et al, 2009a; 2009b; West and Shores, 2011; Bohn-Goldhaum et al, 2013) and six with an unclear risk of bias (Tester and Baker, 2009; Fitzhugh et al, 2010; Branas et al, 2011; Cohen et al, 2012; Veitch et al, 2012; Cohen et al, 2014). The bias-related concerns were allocation sequence (which generally was not possible due to trial design), allocation concealment and blinding of the participants/outcome assessors. None of the studies reported accounting for missing data and risk of contamination was difficult to assess due to the nature of the control group (no study formally measured this).

\section{Evidence Synthesis}

Table 1 presents a summary of the key characteristics and results of the studies categorized according to the type of intervention.

\section{1) Built Environment Only Interventions}

Nine studies investigated the influence of an UGS intervention that involved physical changes to the built environment only. Four studies (three of which were in the USA) showed a positive outcome with increases in PA and park usage (Cohen et al, 2009b; Fitzhugh et al, 2010; Branas et al, 2011; Veitch et al, 2012). Cohen et al (2009b) investigated the impact of two parks that underwent renovations to a skate park and senior center. Results showed a significant increase in skate park use but substantially fewer users of the senior center. There was also a significant increase in the perception of safety in the renovated parks $(\mathrm{p}<0.001)$. An Australian study by Veitch and colleagues (2012) showed significant increases in the number of park users and number of people walking and being vigorously active after major 
park improvements (i.e., fenced leash-free area for dogs, playground, walking track, BBQ area, landscaping, fencing). In another study that included youths, an urban greenway trail (Fitzhugh et al, 2010), designed to enhance connectivity of pedestrian infrastructure with nearby retail establishments and schools, showed significant changes between the experimental and control neighborhoods for total PA ( $p=0.001)$; walking $(p=0.001)$ and cycling ( $\mathrm{p}=0.038)$. However, there was no significant change over time for active transportation to school. Finally, a decade long study using a difference-in-difference design by Branas et al (2011) showed that greening of vacant urban lots resulted in reductions in gun assaults $(\mathrm{p}<0.001)$, vandalism $(\mathrm{p}<0.001)$, and residents reporting less stress and more exercise $(\mathrm{p}<0.01)$. Greening of vacant lots $\left(>725,000 \mathrm{~m}^{2}\right)$ from 1999 to 2008 involved removing trash and debris, grading the land, planting grass and trees, installing low wooden fences around perimeter, and maintenance activities performed multiple times/year.

Five studies (three of which were by the same first author) showed no significant impact on PA and park usage for PA interventions involving change to the built environment only (Cohen et al, 2009a; West and Shores, 2011; Cohen et al, 2012; Bohn-Goldhaum et al, 2013; Cohen et al, 2014). Cohen et al (2009a) showed that park use and PA declined in parks that underwent major improvements including new/improved gyms, picnic areas, walking paths, playgrounds, watering and landscaping. However, during the study period the Department of Recreation and Parks suffered budget cuts that led to reduced programming and the authors suggested that $39 \%$ of the decline was directly attributable to fewer scheduled organized activities. Another Californian study by Cohen et al (2012) found that park usage increased by $11 \%$ compared to control parks (not statistically significant) following the installation of Family Fitness zones (i.e., outdoor gyms) in 12 parks. More recently, Cohen and colleagues (2014) investigated the impact of the creation of three pocket parks from vacant lots on the 
number of park users and PA. This involved installation of playground equipment and benches, development of walking paths, and all areas were fenced and enclosed by lockable gates. Typically, pockets parks serve the immediate population within $0.25-0.5$ miles of the park, have limited facilities, have few or no programs, lack indoor facilities, and are not staffed. Results showed that pocket parks were used as frequently or more often than playground areas in neighborhood parks (control areas); however, they were vacant during the majority of observations. The authors concluded that pocket parks may act as catalysts for PA and encourage local residents to be physically active by being a valued community destination. However, additional strategies and programs may be needed to encourage more residents to use these parks. A study by West and Shores (2011) found no significant effect for PA for five miles of greenway developed and added to existing greenway along a river. Finally, an Australian study targeting 2-12 year old children found no significant effects for park usage and children’s PA compared to the control group following major park renovations involving development of three children's playgrounds within a larger park complex (Bohn-Goldhaum et al, 2013).

\section{2) Physical Activity Promotion Only Interventions}

Only one study investigated the impact of a PA promotion only intervention to encourage use and PA in UGS using a RCT design (Cohen et al, 2013). Fifty-one parks were randomly allocated to one of three groups: 1) Park Directors (PDs) only; 2) Park Directors and Park Advisory Boards (PD-PABs); or 3) control group (measurement only). Park Directors received five training sessions from a marketing consultant regarding outreach, customer service, promotion events, improving park image and building the customer base. Further, the intervention arms used the baseline data collected regarding park use and characteristics of park users from Systems for Observing Play and Recreation in Communities (SOPARC) 
observations (McKenzie et al, 2006) to inform decisions regarding development of park programs to increase park use and PA. Each park received \$4,000 to spend on park programs which included signage (e.g., banners, walking path signs), promotional incentives (e.g., water bottles, park-branded key chains, individually targeted emails), and outreach activities (e.g., hiring additional instructors, buying activity materials). Results showed a significant increase in PA and number of park users for both intervention arms, generating an estimated average of 600 more visits/week/park, and 1830 more MET-hours of PA/week/park. The primary mediator of change was investment in signage which explained $37 \%$ of change in park users and 39\% increase in MET-hours.

\section{3) Combination of Built Environment Change and PA Promotion Intervention}

Two studies investigated interventions that included a combination of both a physical change to the built environment and a PA promotional aspect (Merom et al, 2003; Tester and Baker, 2009). Merom et al (2003) investigated the impact of a promotion campaign of a newly constructed Rail Trail in Western Sydney, Australia. The promotion campaign included press ads, maps of trails, newspapers and local radio, brochures distributed to local organizations and schools, and a launch event. Results showed that trail usage was higher among bikeowners than pedestrians ( $8.9 \%$ vs $2.2 \%, \mathrm{p}=0.014$ ) and was moderated by proximity to the trail. Intervention group cyclists increased mean cycling time by $0.19 \mathrm{hr}$ (SD 1.5) per week while control area cyclists decreased cycling time (-0.24hr; SD 1.6). Overall mean bike counts on the trail increased significantly after the trail launch $(\mathrm{p}=0.0004)$. The study found that remoteness (in distance and time) was a key reason for not using the trail. In another study, by Tester and Baker (2009), significant renovations to playfields (mainly used for soccer and baseball) of two public parks as well as PA programming, and training and skills development for park and recreation program staff were evaluated. Results showed that park 
playfield renovations, with and without family and youth involvement initiatives, significantly increased visitation and overall PA (4-9 fold increase) compared to the control.

\section{Discussion}

In summary, there was some evidence to support the use of built environment only interventions for encouraging use and increasing PA in UGS. However, more promising evidence existed for the use of PA programs combined with a physical change to the built environment. These findings highlight that multifaceted UGS intervention strategies are likely to have a more significant impact on levels of PA than changes to the built environment in isolation. However, these results should be interpreted with caution given the relative dearth of intervention-based research in this area and further work is urgently required (Harris et al, 2013).

Undertaking UGS research requires multi-component studies which incur considerable costs. In addition, the undervaluation of the PA benefits derived from UGS may also explain the relative lack of societal investment in research on UGS. Significant UGS investment is made worldwide, particularly by local authorities (Brown and Cummins, 2013). Thus, more effective strategies for using this valuable resource to enhance opportunities for PA and improve public health are required. Based on this review we have highlighted methodological considerations to help inform the design, implementation and evaluation of future PA interventions in UGS. 
Table 2 details a number of methodological issues raised in this review and highlights a number of recommendations to ensure future robust evaluations of UGS-PA interventions. The implementation of specific recommendations is contingent on the research question.

\section{1) Sample Size}

Only one study reviewed mentioned details of a sample size calculation to inform their study population (Cohen et al, 2013) with most of the included studies employing a small sample size for research of this nature. Future studies must perform a fully justified sample size calculation to improve the rigor of this body of research, and where appropriate, account for clustering.

\section{2) Outcome Measures}

Eight studies used SOPARC for capturing the number of park users, characteristics of park users and their PA levels (Cohen et al, 2009a; 2009b; Tester and Baker, 2009; Cohen et al, 2012; Veitch et al, 2012; Bohn-Goldhaum et al, 2013; Cohen et al, 2013; 2014). SOPARC methodology states that data should only be collected on clement days; the protocol is designed to eliminate the weather variable as an important confounder. However, baseline and follow-up observations should be conducted at the same time of the year to control for seasonal variation, and assessment periods for intervention and control groups should be conducted at the same time to enable accurate comparisons between groups. Studies used a varying number of observation times per day and number of days. Thus, a validated protocol is required in order to compare study findings. Further, given the impact of weather conditions on park usage, detailed weather data should be collected and assessed for the data collection period. 
While SOPARC has a number of strengths it does not capture whether new users are using the park, where park users have come from (local residents or visitors), socio-economic characteristics of park users or individual level change. A number of studies triangulated SOPARC data with Intercept Surveys and household interviews with local residents in order to provide a more in-depth investigation (Cohen et al, 2009a; 2009b; 2012; Bohn-Goldhaum et al, 2013; Cohen et al, 2013; 2014). Further, new technologies, such as the use of web cameras (Hipp et al, 2013; Adlakha et al, 2014), accelerometers and GPS tracking (Kerr et al, 2011; Schipperijn et al, 2014) offer new objective measures of UGS and PA interventions, however they require further methodological testing and understanding of the practical considerations.

It is imperative that future studies measure a range of purported mediators and moderators of initiation and maintenance of PA behavior change in order to test the hypothesized pathways of effect. Examples include perceived and objective measures of UGS safety, distance from UGS, awareness of UGS, barriers to UGS use, motivators for UGS use, weather, exposure to UGS, quality of UGS environment (objective and perceived measures of UGS attributes/features), neighborhood built environment features and, community level social measures such as sense of community, social support and social capital. This requires the use of multi-level conceptual models and statistical methods, and the triangulation of data, both quantitative and qualitative, from multiple sources. Further, it is important that studies report the area of UGS (e.g. $\mathrm{km}^{2}$ ) involved in order to outline the context of the intervention.

\section{3) Follow up}

The timing of follow-up assessments ranged from immediately post-intervention (Veitch et al, 2012) up to 14 months post-intervention (Cohen et al, 2009b; Fitzhugh et al, 2010). 
Further, only one study included more than one measured endpoint which included follow-up assessments immediately post-intervention and a further follow-up 12 months post-baseline (Veitch et al, 2012). Results showed an increase in usage and PA at the first follow-up, which continued to increase at the second follow-up therefore illustrating the need for longerterm follow-up.

It is also unclear what duration of intervention exposure is required to ensure "normal usage" as opposed to capturing the "novelty factor" effect. Given the relative "permanent-ness” of built environment interventions, usage over time will change and this needs to be captured by employing a number of follow-up assessment points from immediately post-construction to longer term follow-up. For example, large scale interventions such as the development of a $£ 32$ million urban greenway has a 40 year management and maintenance strategy (Tully et al, 2013; Dallat et al, 2014). Such interventions provide a unique opportunity and need for longer term follow-ups, for example, at 2 years, 5 years and 10+ years. In regards to followup duration for PA programmes only, a minimum of 1 year follow-up is considered important for assessing maintenance of behaviour change.

\section{4) Control Groups}

Control groups typically involved matched control parks which did not undergo any UGS intervention. Parks were matched on the following criteria: parks of similar size, features, amenities and served a similar population that did not undergo any improvements (Cohen et al, 2009a; 2009b; Tester and Baker, 2009; Bohn-Goldhaum et al, 2013). However, for some studies, the control park $\left(10,000 \mathrm{~m}^{2}\right)$ was only half the size of the intervention park (size 25,200 $\mathrm{m}^{2}$ ), which has obvious implications when measuring number of users (Veitch et al, 2012). 
There is difficulty in identifying adequate control parks of similar sizes, similar features and which serve a similar population (based on socio-economic factors) yet are geographically far enough apart to limit contamination. This is an inherent limitation in that most parks are unique, being, in part, the product of the limited availability of land parcels that are allocated as park space, and the need to "squeeze" park space into what remains after real estate development. Further, other studies employed a control group based on distance from the UGS intervention (1.5-2km (Merom et al, 2003); 0.5-1 mile (West and Shores, 2011)). However, it is unknown what an appropriate distance from the UGS intervention would act as a "true" control, given that a distance decay pattern has been identified (Krizek et al, 2007). However, it is imperative that an adequate control condition is included in order to ensure robust evaluations (Craig et al, 2012).

\section{5) Target Population}

A number of studies targeted low SEP groups and ethnic minority groups which are typical of inner-city areas. Also, most studies were based in the US, particularly in California which has an average of 47 weeks per year with no precipitation. Therefore, further studies are urgently required in other parts of the world, with differing climates, particularly in low-middle income countries. There was also a paucity of evidence related to the influence of PA interventions and UGS on children, adolescents and older adults. A unique aspect of UGS is that it is a resource for people of all ages and backgrounds; therefore, future research should target all groups.

A number of studies highlighted the importance of community participation (Cohen et al, 2009a) and partnerships with local organizations and government (Veitch et al, 2012). It is important that such participation is involved from the outset of the intervention and 
throughout the period of intervention and follow up to ensure sustainability of the intervention and maintenance of PA behavior change.

\section{6) Cost-effectiveness Analyses}

Built environment interventions, in particular those that undertake a physical change to the built environment are expensive and present significant investment, mainly by local authorities. Studies investigated interventions that ranged from $\$ 45,000$ per park (Cohen et al, 2012) to $\$ 3.5$ million per park (Cohen et al, 2009b), with some undertaking preliminary costeffectiveness analyses and finding that UGS interventions are cost-effective (Cohen et al, 2012; 2013; 2014). However, future research should also consider the wider economic impact of such interventions, including health and societal costs, for example, healthcare costs, reductions in carbon emissions, improvements in safety, and reduced crime.

\section{7) Social Environment}

Finally, none of the included studies measured any features of the social environment or utilized aspects of the social environment in the intervention. It is likely that the social environment (e.g., social support, social capital (Broyles et al, 2011)) plays an important role in the initiation and maintenance of PA behavior change in UGS, particularly as most UGS is based within a community setting. Indeed, social support has been identified as an important correlate for PA behavior change (Bauman et al, 2012). Previous cross-sectional research suggests that the social environment may act as a possible mechanism through which UGS positively impacts on health outcomes (Sugiyama et al, 2008; Maas et al, 2009). The social environment is inherent in PA programs and UGS, for example, walking groups, dog walking, where people can meet and “get out and about” (Prior et al, 2014), and be active (with or without realizing it). 
There is a need to move beyond individual level approaches and towards broader population interventions that provide a supportive social and built environment. Future research would be enhanced through incorporating measures of the social environment in order to further understand the role that it plays in PA and UGS research, and how it might be influenced, in association with the built environment, for PA behavior change.

\section{Challenges}

All but one of the studies were natural experiments, i.e., the researchers did not have any input or control in the design and implementation of the intervention. These are particularly complex interventions with multiple interacting factors at the individual, community and population level, and considerable variation in the quality and types of UGS. Studies of this kind raise a number of scientific and evaluative challenges, for example, aligning research timetables with the regeneration timelines, rapidly recruiting and conducting a baseline assessment prior to implementation of the intervention and, measuring confounders and levels of exposure.

Evaluations of such complex interventions need to be scientifically robust yet flexible enough to cope with unpredictable implementation and a changing environment which is not controlled by the researcher. The MRC guidelines for natural experiments recommend the specification of a priori hypotheses, clear definitions of target populations, explicit sampling criteria and the use of valid and reliable outcome measures (Craig et al, 2012). These guidelines should be followed in the design and conduct of future evaluations of PA interventions in UGS to improve the scientific rigor of the research. In addition, the RE-AIM Framework (King et al, 2010) provides a useful template to guide the design and 
implementation of a comprehensive public health evaluation of large built environment interventions, expanding the assessment of interventions beyond efficacy to address multiple criteria, including Reach, Effectiveness, Adoption, Implementation and Maintenance, that better assess the potential for dissemination and public health impact of such interventions.

\section{Unanswered Questions}

In addition to detailing a number of methodological considerations, this review has also highlighted gaps in the literature. The following unanswered questions will help focus future research:

1. Do specific UGS improvements result in increased UGS usage and PA among specific groups (e.g., low SEP, different age groups, gender)?

2. Is it possible to design multi-use and multi-purpose UGS that facilitates increased PA for a wide number of user groups, for example different age groups, in different climates, cultures and countries?

3. Do improvements to UGS of varying sizes and/or functions result in similar increases in UGS usage and PA?

4. To what extent do interventions actually capture new UGS users?

5. Do increases in PA from UGS interventions result in the displacement of PA from other areas?

6. Does regular UGS usage equate to regular PA participation?

7. To what extent can marketing and outreach programs maintain early behavior change from improvements in the built environment?

8. What role does the social environment play in the uptake, initiation and maintenance of PA behavior change in UGS? 
9. How can the unique 'natural' features of UGS be used to support people's need for contact with nature and facilitate increased PA?

\section{Conclusion}

Physical inactivity is a major public health concern, with implications for our health, society and economy. The public health dividend of increasing PA in the population is substantial. UGS has the potential to contribute significantly to public health as a setting that encourages participation in PA. Physical activity behavior change at the community and population level might be increased by interventions specifically targeting use of UGS (Cohen et al, 2007). Results from this review show promising evidence to support the use of PA programs and physical changes to the built environment for increasing UGS use and PA. There are multiple strategies for increasing PA in UGS and future work should explore these. Focused attention to the issues raised in this review is likely to lead to more robust evaluations of interventions to promote the use of and PA in UGS and contribute to improving public health. This review provides a platform for guiding the design, implementation and evaluation of future research investigating PA interventions and UGS research. 


\section{References}

Adlakha, D., Budd, E.L., Gernes, R., Sequeira, S., \& Hipp, J.A. (2014). Use of emerging technologies to assess differences in outdoor physical activity in St. Louis, Missouri. Frontiers in Public Health, 2, 41.

Bauman, A.E., Reis, R.S., Sallis, J.F., Wells, J.C., Loos, R.J., Martin, B.W,. \& the Lancet Physical Activity Series Working Group. (2012). Correlates of physical activity: why are some people physically active and others not? Lancet, 380(9838), 258-271.

Bedimo-Rung, A.L., Mowen, A.J., \& Cohen, D.A. (2005). The significance of parks to physical activity and public health: a conceptual model. American Journal of Preventive Medicine, 82(2 suppl 2), 159-168.

Bohn-Goldhaum, E., Phongsavan, P., Merom, D., Rogers, K., Kamalesh, V., \& Bauman, A.E. (2013). Does playground improvement increase physical activity among children? A quasiexperimental study of a natural experiment. Journal of Environmental and Public Health, 109841.

Bowler, D.E., Buyung-Ali, L.M., Knight, T.M., \& Pullin, A.S. (2010). A systematic review of evidence for the added benefits to health of exposure to natural environments. BMC Public Health, 10, 456.

Branas, C.C., Cheney, R.A., MacDonald, J.M., Tam, V.W., Jackson, T.D., \& Ten Have,T.R. (2011). A difference-in-differences analysis of health, safety, and greening vacant urban space. American Journal of Epidemiology, 174(11), 1296-1306. 
Brown, T., \& Cummins, S. Intervening in health: The place of urban green space. Landsc Urban Plan 2013;118:59-61.

Broyles, S.T., Mowen, A.J., Theall, K.P., Gustat, J., \& Rung, A.L. (2011).

Integrating social capital into a park-use and active-living framework. American Journal of Preventive Medicine, 40(5), 522-529.

Cohen, D., Sehgal, A., Williamson, S., Golinelli, D., Lurie, N., \& McKenzie, T.L. (2007). Contribution of public parks to physical activity. American Journal of Public Health , 97, $509-514$.

Cohen, D.A., Golinelli, D., Williamson, S., Sehgal, A., Marsh, T., \& McKenzie, T.L. (2009a). Effects of park improvements on park use and physical activity: policy and programming implications. American Journal of Preventive Medicine, 37(6), 475-480.

Cohen, D.A., Sehgal, A., Williamson, S., Marsh, T., Golinelli, D., \& McKenzie, T.L. (2009b). New recreational facilities for the young and the old in Los Angeles: policy and programming implications. Journal of Public Health Policy, 30(Suppl 1), S248-263.

Cohen, D.A., Marsh, T., Williamson, S., Derose, K.P., Martinez, H., Setodji, C., \& McKenzie, T.L. (2010). Parks and physical activity: why are some parks used more than others? Preventive Medicine, 50(Suppl 1), S9-12. 
Cohen, D.A., Marsh, T., Williamson, S., Golinelli, D., \& McKenzie, T.L. (2012). Impact and cost-effectiveness of family Fitness Zones: a natural experiment in urban public parks. Health and Place, 18(1), 39-45.

Cohen, D.A., Han, B., Derose, K.P., Williamson, S., Marsh, T., \& McKenzie, T.L. (2013). Physical activity in parks: A randomized controlled trial using community engagement. American Journal of Preventive Medicine, 45(5), 590-597.

Cohen, D.A., Marsh, T., Williamson, S., Han, B., Derose, K.P., Golinelli, D., \& McKenzie, T.L. (2014). The potential for pocket parks to increase physical activity. American Journal of Health Promotion, 28(3 Suppl), S19-26.

Craig, P., Cooper, C., Gunnell, D., Haw, S., Lawson, K., Macintyre, S., ... Thompson, S. (2012). Using natural experiments to evaluate population health interventions: new Medical Research Council guidance. Journal of Epidemiology and Community Health, 66, 11821186.

Dallat, M.A., Soerjomataram, I., Hunter, R.F., Tully, M.A., Cairns, K.J., \& Kee, F. (2014). Urban greenways have the potential to increase physical activity levels cost-effectively. European Journal of Public Health, 24(2), 190-195.

Department of Health. (2007). Foresight: Tackling Obesities: Future Choices. Preventing Chronic Disease, 4, 87. 
Fitzhugh, E.C., Bassett, D.R. Jr., \& Evans, M.F. (2010). Urban trails and physical activity: a natural experiment. American Journal of Preventive Medicine, 39(3), 259-262.

Floyd, M.F., Spengler, J.O., Maddock, J.E., Gobster, P.H., \& Suau, L.J. (2008). Park-based physical activity in diverse communities of two U.S. cities. An observational study. American Journal of Preventive Medicine, 34(4), 299-305.

Floyd, M.F., Bocarro, J.N., Smith, W.R., Baran, P.K., Moore, R.C., Cosco, N.G., ... Fang, K. (2011). Park-based physical activity among children and adolescents. American Journal of Preventive Medicine, 41(3), 258-265.

Giles-Corti, B., Broomhall, M.H., Knuiman, M., Collins, C., Douglas, K., Ng, K., ... Donovan, R.J. (2005). Increasing walking: how important is distance to, attractiveness, and size of public open space? American Journal of Preventive Medicine, 28(2 suppl 2), 169-176.

Harris, J.K., Lecy, J., Parra, D.C., Hipp, J.A., Brownson, R.C. (2013). Mapping the development of research on physical activity and the built environment. Preventive Medicine, 57(5), 533-540.

Higgins, J.P., Altman, D.G., Gøtzsche, P.C., Jüni, P., Moher, D., Oxman, A.D., ... Sterne, J.A. (2011). The Cochrane Collaboration's tool for assessing risk of bias in randomised trials. British Medical Journal, 343, d5928. 
Hipp, J.A., Adlakha, D., Eyler, A.A., Chang, B., \& Pless, R. (2013). Emerging technologies: Webcams and crowd-sourcing to identify active transportation. American Journal of Preventive Medicine, 44(1),96-97.

Kaczynski, A.T., Wilhelm Stanis, S.A., Hastmann, T.J., \& Besenyi, G.M. (2011). Variations in observed park physical activity intensity level by gender, race, and age: individual and joint effects. Journal of Physical Activity and Health, 8(Suppl 2), S151-160.

Kerr, J., Duncan, S., \& Schipperijn, J. (2011). Using global positioning systems in health research: a practical approach to data collection and processing. American Journal of Preventive Medicine, 41(5),532-540.

Khan, K.M., Weiler, R., \& Blair, S.N. (2011). Prescribing exercise in primary care. British Medical Journal, 343, d4141.

King, D.K., Glasgow, R.E., \& Leeman-Castilllo, B. (2010). Reaiming REAIM: Using the model to plan, implement and evaluate the effects of environmental change approaches to enhancing population health. American Journal of Public Health, 100, 2076-2084.

Krizek, K.J., El-Geneidy, A., \& Thompson, K. (2007). A detailed analysis of how an urban trail system affects cyclists' travel. Transportation, 34(5), 611-624.

Lachowycz, K., \& Jones, A.P. (2011). Greenspace and obesity: a systematic review of the evidence. Obesity Reviews, 12(5), e183-9. 
Lee, A.C.K., \& Maheswaran, R. (2010). The health benefits of urban green spaces: a review of the evidence. Journal of Public Health, 33(2), 212-222.

Lee, I.M., Shiroma, E.J., Lobelo, F., Puska, P., Blair, S.N., Katzmarzyk, P.T., \& the Lancet Physical Activity Series Working Group. (2012). Effect of physical inactivity on major noncommunicable diseases worldwide: an analysis of burden of disease and life expectancy. Lancet, 380, 219-229.

Maas, J., van Dillen, S.M., Verheij, R.A., \& Groenewegen, P.P. (2009). Social contacts as a possible mechanism behind the relation between green space and health. Health and Place, 15(2), 586-595.

McKenzie, T.L., Cohen, D.A., Sehgal, A., Williamson, S., \& Golinelli, D. (2006). System for Observing Play and Recreation in Communities (SOPARC): Reliability and feasibility measures. Journal of Physical Activity and Health, 3(Suppl 1), S208-S222.

Merom, D., Bauman, A., Vita, P., \& Close, G. (2003). An environmental intervention to promote walking and cycling-the impact of a newly constructed Rail Trail in Western Sydney. Preventive Medicine, 36(2), 235-242.

Moher, D., Liberati, A., Tetzlaff, J., \& Altman, D.G. (2009). The PRISMA Group. Preferred Reporting Items for Systematic Reviews and Meta-Analyses: The PRISMA Statement. Annals of Internal Medicine, 151(4), 264-269. 
Mowen, A., Orsega-Smith, E., Payne, L., Ainsworth, B., \& Godbey, G. (2007). The role of park proximity and social support in shaping park visitation, physical activity, and perceived health among older adults. Journal of Physical Activity and Health, 4(2), 167-179.

O Ferdinand, A., Sen, B., Rahurkar, S., Engler, S., \& Menachemi, N. (2012). The relationship between built environments and physical activity: a systematic review. American Journal of Public Health, 102(10), e7-e13.

Prior, L., Scott, D., Hunter, R., Donnelly, M., Tully, M.A., Cupples, M.E., \& Kee, F. (2014). Exploring lay views on physical activity and their implications for public health policy. A case study from East Belfast. Social Science and Medicine, 114, 73-80.

Schipperijn, J., Bentsen, P., Troelsen, J., Toftager, M., \& Stigsdotter, U.K. (2013). Associations between physical activity and characteristics of urban green space. Urban Forestry and Urban Greening, 12(1), 109-116.

Schipperijn, J., Kerr, J., Duncan, S., Madsen, T., Klinker, C.D., \& Troelsen, J. (2014). Dynamic accuracy of GPS receivers for use in health research: A novel method to assess GPS accuracy in real-world settings. Frontiers in Public Health, 2, 21.

Sugiyama, T., Leslie, E., Giles-Corti, B., \& Owen, N. (2008). Associations of neighbourhood greenness with physical and mental health: do walking, social coherence and local social interaction explain the relationships? Journal of Epidemiology and Community Health, 62(5), e9 
Tester, J., \& Baker, R. (2009). Making the playfields even: evaluating the impact of an environmental intervention on park use and physical activity. Preventive Medicine, 48(4), 316-320.

Tully, M.A., Hunter, R.F., McAneney, H., Cupples, M.E., Donnelly, M., Ellis. G., ... Kee F. (2013). Physical activity and the rejuvenation of Connswater (PARC study): protocol for a natural experiment investigating the impact of urban regeneration on public health. $B M C$ Public Health, 13, 774.

Veitch, J., Ball, K., Crawford, D., Abbott, G.R., \& Salmon, J. (2012). Park improvements and park activity: a natural experiment. American Journal of Preventive Medicine, 42(6), 616619.

West, S.T., \& Shores, K.A. (2011). The impacts of building a greenway on proximate residents' physical activity. Journal of Physical Activity and Health, 8(8), 1092-1097.

World Health Organization. (2010). Global recommendations on physical activity for health. http://whqlibdoc.who.int/publications/2010/9789241599979_eng.pdf 
Table 1: Summary of included studies

\begin{tabular}{|c|c|c|c|c|c|c|c|c|c|}
\hline \multirow[b]{2}{*}{ Reference } & \multirow[b]{2}{*}{ Study Design } & \multicolumn{3}{|c|}{ Study Descriptor } & \multirow[b]{2}{*}{ Control } & \multicolumn{4}{|c|}{ Results } \\
\hline & & Country & Population & Intervention & & Outcome & 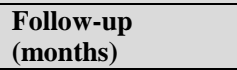 & Outcome Measures & $\begin{array}{l}\text { Risk of } \\
\text { Bias }\end{array}$ \\
\hline \multicolumn{10}{|c|}{ Change to built environment only } \\
\hline $\begin{array}{l}\text { Cohen et } \\
\text { al, 2009a }\end{array}$ & $\begin{array}{l}\text { Quasi- } \\
\text { experiment: } \\
\text { controlled, pre- } \\
\text { post design }\end{array}$ & US & $\begin{array}{l}\text { Predominantly } \\
\text { Latino and } \\
\text { African- } \\
\text { American and } \\
\text { low-income } \\
\text { neighborhoods } \\
\text { (mean } 31 \% \text { of } \\
\text { households in } \\
\text { poverty) }\end{array}$ & $\begin{array}{l}5 \text { parks (mean } 8 \\
\text { acres) underwent } \\
\text { major improvements } \\
\text { including } \\
\text { new/improved gyms, } \\
\text { picnic areas, walking } \\
\text { paths, playgrounds, } \\
\text { watering and } \\
\text { landscaping (cost: } \\
\text { >\$1m each) }\end{array}$ & $\begin{array}{l}\text { Each intervention park } \\
\text { had a matched control } \\
\text { park }(\mathrm{n}=5) \text { of similar size, } \\
\text { features, amenities and } \\
\text { served a similar } \\
\text { population that did not } \\
\text { undergo any } \\
\text { improvements }\end{array}$ & $\begin{array}{l}\text {-ve: Overall park use } \\
\text { and PA declined in } \\
\text { both intervention and } \\
\text { control parks }\end{array}$ & $\begin{array}{l}\text { Baseline (Dec } \\
\text { 2003-Nov 2004); } \\
\text { follow-up (Apr } \\
\text { 2006-Mar 2008) } \\
\text { Follow up } \\
\text { measures were } \\
\text { initiated at least } 3 \\
\text { months after } \\
\text { construction (range } \\
\text { 3-14 months post } \\
\text { construction) }\end{array}$ & $\begin{array}{l}\text { SOPARC: } 4 \text { time points over } 7 \\
\text { days } \\
\text { Intercept surveys } \\
\text { Interviews with residents } \\
\text { within } 1-2 \text { miles from each } \\
\text { park: use of park and PA levels }\end{array}$ & High \\
\hline $\begin{array}{l}\text { Cohen et } \\
\text { al, 2009b }\end{array}$ & $\begin{array}{l}\text { Quasi- } \\
\text { experiment: } \\
\text { controlled, pre- } \\
\text { post design }\end{array}$ & US & $\begin{array}{l}\text { Residents living } \\
\text { within } 2 \text { mile } \\
\text { radius of parks } \\
\text { Youths and } \\
\text { seniors }\end{array}$ & $\begin{array}{l}2 \text { parks (48-67 acres) } \\
\text { underwent } \\
\text { renovations: (1) } \\
\text { improvements to } \\
\text { skate park surfaces } \\
\text { only (cost } \$ 3.5 \mathrm{~m}) \\
\text { (2) improvements to } \\
\text { entrance, courtyard } \\
\text { areas and } \\
\text { gymnasium of senior } \\
\text { center (cost } \$ 3.3 \mathrm{~m} \text { ) }\end{array}$ & $\begin{array}{l}\text { Control skate park and } \\
\text { control senior center that } \\
\text { did not have any } \\
\text { improvements } \\
\text { matched on neighborhood } \\
\text { characteristics } \\
\text { (demographics and } \\
\text { economic distribution) } \\
\text { and physical features } \\
\text { (size and type of } \\
\text { facilities) }\end{array}$ & $\begin{array}{l}\text { +ve: } 510 \% \text { increase in } \\
\text { skate park use } \\
\text { compared to } 77 \% \text { in } \\
\text { comparison skate park } \\
\text { Substantially fewer } \\
\text { users of senior center }\end{array}$ & $\begin{array}{l}\text { Baseline and } \\
\text { follow-up 1-3 } \\
\text { months following } \\
\text { opening of } \\
\text { renovated areas }\end{array}$ & $\begin{array}{l}\text { SOPARC: } 4 \text { timepoints over } 7 \\
\text { days } \\
\text { Face to face interviews with } \\
\text { park users and residents (age } \\
\text { 18+) living within a 2-mile } \\
\text { radius of park } \\
\text { Perception of safety; park } \\
\text { proximity; }\end{array}$ & High \\
\hline $\begin{array}{l}\text { Fitzhugh } \\
\text { et al, } 2010\end{array}$ & $\begin{array}{l}\text { Quasi- } \\
\text { experiment: } \\
\text { controlled, pre- } \\
\text { post design }\end{array}$ & US & $\begin{array}{l}\text { Children, } \\
\text { adolescents and } \\
\text { adults in free- } \\
\text { living } \\
\text { conditions in } \\
\text { neighborhood } \\
(17.7 \% \text { ethnic } \\
\text { minority; } \\
32.2 \% \text { living in } \\
\text { poverty) }\end{array}$ & $\begin{array}{l}\text { Retrofit of an urban } \\
\text { greenway/trail ( } 2.9 \\
\text { miles long) to } \\
\text { enhance connectivity } \\
\text { of pedestrian } \\
\text { infrastructure with } \\
\text { nearby retail } \\
\text { establishments and } \\
\text { schools (cost: } \\
\$ 2.1 \mathrm{~m})\end{array}$ & $\begin{array}{l}2 \text { control neighborhoods } \\
\text { with similar } \\
\text { socioeconomic } \\
\text { dimensions and } 2 \\
\text { elementary and } 1 \text { middle } \\
\text { control schools }\end{array}$ & $\begin{array}{l}\text { +ve: Pre and post } \\
\text { intervention changes } \\
\text { between experimental } \\
\text { and control } \\
\text { neighborhoods were } \\
\text { sig different for total } \\
\text { PA (p=0.001); walking } \\
\text { (p=0.001) and cycling } \\
\text { ( }=0.038) \\
\text { There was no sig } \\
\text { change over time for } \\
\text { active transport to } \\
\text { school }\end{array}$ & $\begin{array}{l}\text { Baseline (Mar } \\
\text { 2005) and follow- } \\
\text { up (Mar 2007) } 14 \\
\text { months after } \\
\text { construction } \\
\text { complete }\end{array}$ & $\begin{array}{l}\text { Pedestrian count surveys at } \\
\text { school and neighborhood areas } \\
\text { ( } 2 \text { hours on } 2 \text { days) for } 1 \text {-week } \\
\text { at baseline and follow-up }\end{array}$ & Unclear \\
\hline $\begin{array}{l}\text { Branas et } \\
\text { al, } 2011\end{array}$ & $\begin{array}{l}\text { Quasi- } \\
\text { experiment: }\end{array}$ & US & $\begin{array}{l}\text { Cohort of } \\
50000\end{array}$ & $\begin{array}{l}\text { Greening of vacant } \\
\text { urban land }(n=4436)\end{array}$ & $\begin{array}{l}\text { Matched control vacant } \\
\text { lots }(\mathrm{n}=13,300) \text { were }\end{array}$ & $\begin{array}{l}\text { +ve: Greening } \\
\text { associated with }\end{array}$ & $\begin{array}{l}\text { Southeastern } \\
\text { Pennsylvania }\end{array}$ & $\begin{array}{l}\text { Survey included self-report } \\
\text { question of PA levels }\end{array}$ & Unclear \\
\hline
\end{tabular}


difference in

difference design
Philadelphians

from household

survey

\begin{tabular}{llll}
\hline $\begin{array}{l}\text { West and } \\
\text { Shores, }\end{array}$ & $\begin{array}{l}\text { Quasi- } \\
\text { experiment: } \\
2011\end{array}$ & US & Residents \\
& controlled, pre- & & within 0.5 mile \\
& post design & & radius of \\
& & greenway in \\
& & midsized \\
& & Southeastern \\
& & US city, owned \\
& & a single-family \\
& & dwelling (90\%
\end{tabular}

multiple times/year

\begin{tabular}{|c|c|c|c|c|}
\hline & & & Caucasian) & \\
\hline $\begin{array}{l}\text { Cohen et } \\
\text { al, } 2012\end{array}$ & $\begin{array}{l}\text { Quasi- } \\
\text { experiment: } \\
\text { controlled, pre- } \\
\text { post design }\end{array}$ & US & $\begin{array}{l}\text { Residents } \\
\text { within } 1 \text { mile } \\
\text { radius of parks } \\
\text { (mean } 29 \% \text { of } \\
\text { households in } \\
\text { poverty, } 59 \% \\
\text { Latino } \\
\text { population) }\end{array}$ & $\begin{array}{l}12 \text { parks (mean } 14 \\
\text { acres) involving } \\
\text { installation of } \\
\text { Family Fitness zones } \\
\text { (outdoor gyms), } 8 \\
\text { pieces of equipment } \\
\text { at each park (average } \\
\text { cost } \$ 45,000 \text { for } \\
\text { each park) }\end{array}$ \\
\hline
\end{tabular}

$\left(>725000 \mathrm{~m}^{2}\right)$ from

1999 to 2008

involving removin

trash and debris,

grading the land,

planting grass and

trees, installing low

wooden fences

around perimeter;

maintenance

activities performed

randomly selected and

matched to intervention

lots at a 3:1 ratio

reductions in gun

vandalism $(\mathrm{p}<0.001)$,

residents reporting less

stress and more

exercise $(\mathrm{p}<0.01)$

developed and added

to existing greenway

along a river

living 0.5-1 mile radius

from greenway

-ve: No sig difference

between intervention

and control group

However, increases

were observed in the

mean number of days

in which respondents

walked or were

moderately active for

both groups

10 matched control parks

hat did not instll Farks

that did not install Fam ily

-ve: Park usage

increased by $11 \%$

compared to control

parks but this was not

statistically significant

Self-reports of being a

new park user

increased more in

Fitness Zones parks

and estimated energy

expenditure in Fitness

Zones parks was

higher at both follow-

ups than at baseline assaults $(\mathrm{p}<0.001)$,

households $(n=591)$

Household Health

Survey (random

digit dialing every

2 years to a new

cohort of 50000

Philadelphians)

2008

$\begin{array}{ll}\begin{array}{l}\text { Baseline and } \\ \text { follow-up } \\ \text { (conducted 11 }\end{array} & \begin{array}{l}\text { Household survey included } \\ \text { self-report question of PA } \\ \text { months after the }\end{array} \\ \begin{array}{l}\text { levels } \\ \text { opening of the }\end{array} & \\ \text { greenway) } & \end{array}$

\section{Baseline (winter of}

2008-2009); $1^{\text {st }}$

follow-up 1 year

later during winte

(2009-2010; 2

months thereafter

(Spring 2010)

*for control parks

the timing of data

collection from

baseline to follow-

up was an average

of 2 years

compared to 1 year

in the intervention

parks

\begin{tabular}{lllll}
\hline Veitch et & Quasi- & Australia & Most & 1 park (size \\
al, 2012 & experiment: & & disadvantaged & $\left.25,200 \mathrm{~m}^{2}\right)$ : involving \\
& controlled, pre- & & decile in state \\
& of Victoria & establishment of a \\
& post design & & fenced leash-free \\
& & & area for dogs \\
& & & $\left(12,800 \mathrm{~m}^{2}\right)$; an all- \\
& & & abilities playground; \\
& & & a $365 \mathrm{~m}$ walking
\end{tabular}

1 matched control park

+ve: Sig. increase

from pre to post-

Baseline (Aug-

Sept 2009)

$\begin{array}{lll}\text { in same neighborhood as } & \text { improvement in } & \text { immediately } \\ \text { intervention park and } & \text { number of park users } & \text { following park }\end{array}$

having similar features at for intervention park improvement

baseline

$(\mathrm{T} 1=235, \mathrm{~T} 3=985)$ and

number of people

(Mar-Apr 2010)

and 12 months

after baseline
SOPARC 3 times per day for 4 Unclear

days Intercept survey: use of

park, use of fitness equipment,

of park, distance

travelled to park

SOPARC: 7 times each day on Unclear

9 days (over 4 weeks) 


\begin{tabular}{|c|c|c|c|c|c|c|c|c|c|}
\hline & & & & $\begin{array}{l}\text { track; BBQ area; } \\
\text { landscaping; fencing } \\
\text { to prevent motor } \\
\text { vehicle access to the } \\
\text { park }\end{array}$ & & $\begin{array}{l}\mathrm{T} 3=369) \text { and being } \\
\text { vigorously active } \\
\text { (T1=38, } \mathrm{T} 3=257) \text {. }\end{array}$ & (Aug-Sept 2010) & & \\
\hline $\begin{array}{l}\text { Bohn- } \\
\text { Goldbaum } \\
\text { et al, } 2013\end{array}$ & $\begin{array}{l}\text { Quasi- } \\
\text { experiment: } \\
\text { controlled, pre- } \\
\text { post design }\end{array}$ & Australia & $\begin{array}{l}\text { Lower socio- } \\
\text { economic urban } \\
\text { neighborhood } \\
\text { within the city } \\
\text { of Sydney, } \\
\text { Australia. } \\
\text { Targeted } \\
\text { children aged 2- } \\
12 \text { years and } \\
\text { their parents }\end{array}$ & $\begin{array}{l}1 \text { park (size } 4.6 \\
\text { hectares): involving } \\
3 \text { new children's } \\
\text { playgrounds } \\
\text { dispersed throughout } \\
\text { the park. Playground } \\
\text { features include } \\
\text { public art, aboriginal } \\
\text { theme, water feature, } \\
\text { swings, climbing } \\
\text { structure, soft-fall } \\
\text { feature, wood chip } \\
\text { flooring, basketball } \\
\text { and skating area. } \\
\text { Also, upgrading } \\
\text { paths, adding new } \\
\text { greenery, lighting } \\
\text { and facilities, sports } \\
\text { field opened for } \\
\text { public use increasing } \\
\text { the accessible park } \\
\text { size from 2.2-4.6 } \\
\text { hectares }\end{array}$ & $\begin{array}{l}1 \text { matched control park } \\
\text { (size } 4.2 \text { hectares) located } \\
\text { in located in nearby urban } \\
\text { neighborhood (population } \\
\text { generally socio- } \\
\text { economically similar to } \\
\text { intervention park); both } \\
\text { parks included a } \\
\text { playground, a large open } \\
\text { area, and a sports field }\end{array}$ & $\begin{array}{l}\text {-ve: No sig difference } \\
\text { between groups for } \\
\text { park usage or } \\
\text { children's MVPA } \\
\text { At the intervention } \\
\text { park, there was a } \\
\text { significant decline in } \\
\text { girls engaging in } \\
\text { MVPA at follow-up } \\
(p=0.04)\end{array}$ & $\begin{array}{l}\text { Baseline (May } \\
\text { 2007) and } 9 \\
\text { months after the } \\
\text { park upgrade was } \\
\text { completed (May } \\
\text { 2009) }\end{array}$ & $\begin{array}{l}\text { Observations of playground } \\
\text { visitors aged 2-12 years old } \\
\text { using SOPARC; conducted } \\
\text { during 2-hour periods, } 3 \text { times } \\
\text { per day over a 2-week period } \\
\text { Intercept survey with adults } \\
\text { accompanied by children: } \\
\text { parent’s demographics, PA } \\
\text { behavior and park usage }\end{array}$ & High \\
\hline $\begin{array}{l}\text { Cohen et } \\
\text { al, } 2014\end{array}$ & $\begin{array}{l}\text { Quasi- } \\
\text { experiment: post- } \\
\text { test only } \\
\text { comparison }\end{array}$ & US & $\begin{array}{l}\text { Residents living } \\
\text { within } 0.5 \text { mile } \\
\text { radius of parks } \\
\text { High rates of } \\
\text { household } \\
\text { poverty (30- } \\
41 \% \text { ) and } \\
\text { minority } \\
\text { populations } \\
\text { (70-80\% } \\
\text { Latino, 3-17\% } \\
\text { African- } \\
\text { American, } 0- \\
16 \% \text { Asian) }\end{array}$ & $\begin{array}{l}\text { Creation of } 3 \text { pocket } \\
\text { parks ( } 0.15-0.32 \\
\text { acres) from vacant } \\
\text { lots and undesirable } \\
\text { urban parcels } \\
\text { Playground } \\
\text { equipment and } \\
\text { benches installed, } \\
\text { walking path } \\
\text { developed around } \\
\text { the perimeter, all } \\
\text { fenced and enclosed } \\
\text { by lockable gates } \\
\text { (average cost } \$ 1 \mathrm{~m} \\
\text { each funded by local } \\
\text { non-profit groups) }\end{array}$ & $\begin{array}{l}15 \text { playground areas in } \\
\text { neighborhood parks (15- } \\
50 \text { times larger than } \\
\text { pocket parks) matched to } \\
\text { each pocket park by \% of } \\
\text { households in poverty }\end{array}$ & $\begin{array}{l}\text {-ve: Pocket parks were } \\
\text { used as frequently or } \\
\text { more often than } \\
\text { playground areas in } \\
\text { neighborhood parks. } \\
\text { However, they were } \\
\text { vacant during the } \\
\text { majority of } \\
\text { observations }\end{array}$ & $\begin{array}{l}\text { Baseline (mid } \\
\text { July-mid Aug } \\
\text { 2006) and follow- } \\
\text { up (same season } \\
\text { 2008) and } \\
\text { comparison parks } \\
\text { in 2008-2009 }\end{array}$ & $\begin{array}{l}\text { SOPARC: } 4 \text { times per day } \\
\text { over } 7 \text { days } \\
\text { Surveyed park users and } \\
\text { residents about park use } \\
\text { Random sample of household } \\
\text { addresses (n=824) within } 0.25 \\
\text { miles of pocket park and } \\
\text { another between } 0.25-0.5 \\
\text { miles of the park was selected, } \\
\text { field staff went door to door to } \\
\text { conduct the surveys (adults } \\
18+\text { yrs) }\end{array}$ & Unclear \\
\hline \multicolumn{10}{|c|}{ Physical activity programming intervention only } \\
\hline $\begin{array}{l}\text { Cohen et } \\
\text { al, } 2013\end{array}$ & $\begin{array}{l}\text { RCT: parks } \\
\text { randomized to } 3\end{array}$ & US & $\begin{array}{l}\text { Parks users and } \\
\text { residents living }\end{array}$ & $\begin{array}{l}2 \text { intervention } \\
\text { groups: }\end{array}$ & $\begin{array}{l}17 \text { control parks: } \\
\text { measurement only }\end{array}$ & $\begin{array}{l}\text { +ve: In both PD-only } \\
\text { and PAB-PD parks, }\end{array}$ & $\begin{array}{l}\text { Baseline (Apr } \\
\text { 2008-Mar 2010) }\end{array}$ & $\begin{array}{l}\text { SOPARC ( } 4 \text { times per day } \\
\text { over } 7 \text { days) }\end{array}$ & Low \\
\hline
\end{tabular}


study arms (17

parks per study

arm)

Eligible parks

randomized based

on park size,

number of

facilities and

programs offered

by the park and

socio-

demographic

haracteristics of

e pop within 1

mile radius within 1 mile

radius of park

1) $P$

involved in all

aspects of research

and in using baseline

results to design

park-specific

increase park use and

PA;

PDs received 5

training sessions

from a marketing

consultant

Each park received

$\$ 4000$ to spend on

signage; promotional

incentives; outreach

and support for

\begin{tabular}{|c|c|c|c|c|c|c|c|c|c|}
\hline \multicolumn{10}{|c|}{ Combination of built environment and physical activity programming intervention } \\
\hline $\begin{array}{l}\text { Merom et } \\
\text { al, } 2003\end{array}$ & $\begin{array}{l}\text { Pre and post } \\
\text { population based } \\
\text { telephone survey }\end{array}$ & Australia & $\begin{array}{l}\text { Random sample } \\
\text { of adults aged } \\
18-55 \text { years } \\
\text { within } 1.5 \mathrm{~km} \text { of } \\
\text { the trail }\end{array}$ & $\begin{array}{l}\text { Promotional } \\
\text { campaign of newly } \\
\text { constructed Rail } \\
\text { Trail to develop } \\
\text { community } \\
\text { awareness of the } \\
\text { facility. Media } \\
\text { components included } \\
\text { press ads, map of } \\
\text { trail, newspapers and } \\
\text { local radio, brochure } \\
\text { distributed to local } \\
\text { organizations, } \\
\text { schools, (over } \\
\text { 17000); launch event } \\
\text { and in site promotion } \\
\text { at } 9 \text { City Rail } \\
\text { stations (15000 } \\
\text { brochures distributed } \\
\text { to commuters over } 4 \\
\text { days) } \\
\end{array}$ & $\begin{array}{l}\text { Random sample of adults } \\
\text { aged } 18-55 \text { years } 1.5-2 \mathrm{~km} \\
\text { from trail }\end{array}$ & $\begin{array}{l}\text { +ve: Trail usage was } \\
\text { higher among bike- } \\
\text { owners than } \\
\text { pedestrians ( } 8.9 \% \text { vs } \\
2.2 \%, \mathrm{p}=0.014) \text { and } \\
\text { was moderated by } \\
\text { proximity to trail } \\
\text { Intervention group } \\
\text { cyclists increased } \\
\text { mean cycling time by } \\
0.19 \mathrm{hr} \text { (SD 1.5) while } \\
\text { control area cyclists } \\
\text { decreased cycling time } \\
\text { (-0.24hr; SD 1.6) } \\
\text { Mean bike counts } \\
\text { increased sig after trail } \\
\text { launch ( }=0.0004)\end{array}$ & $\begin{array}{l}\text { Pre-campaign } \\
\text { survey (Nov-Dec) } \\
\text { and post campaign } \\
\text { survey (Mar) }\end{array}$ & $\begin{array}{l}\text { Objective concurrent } \\
\text { monitoring of daily bike } \\
\text { counts (4 locations along trail } \\
\text { Oct 2000-Mar 2001). } \\
\text { Survey included questions on } \\
\text { walking and cycling behavior, } \\
\text { short term intention to be more } \\
\text { active, awareness of trail, } \\
\text { barriers for trail use, purpose } \\
\text { of use, likelihood of future use }\end{array}$ & High \\
\hline $\begin{array}{l}\text { Tester and } \\
\text { Baker, } \\
2009\end{array}$ & $\begin{array}{l}\text { Quasi- } \\
\text { experiment: } \\
\text { controlled, pre- } \\
\text { post design }\end{array}$ & US & $\begin{array}{l}\text { Low-income } \\
\text { neighborhoods } \\
\text { in San } \\
\text { Francisco, } \\
\text { California }\end{array}$ & $\begin{array}{l}2 \text { public parks } \\
\text { underwent } \\
\text { significant } \\
\text { renovations to their } \\
\text { playfields mainly }\end{array}$ & $\begin{array}{l}1 \text { control park: selected } \\
\text { because of similar } \\
\text { socioeconomic and } \\
\text { racial/ethnic } \\
\text { demographics of nearby }\end{array}$ & $\begin{array}{l}\text { Both intervention } \\
\text { parks playfields saw } \\
\text { sig increases in male } \\
\text { and female visitors, } \\
\text { with over a 4-fold }\end{array}$ & $\begin{array}{l}\text { Baseline (late } \\
\text { May) 2006; } \\
\text { follow-up 2007 }\end{array}$ & $\begin{array}{l}\text { SOPARC } 8 \text { times per day over } \\
7 \text { days }\end{array}$ & Unclear \\
\hline
\end{tabular}

PA increased, and in same season Survey of random sample of generating an at follow-up (Apr residents living within 1 mile estimated average of 2010-Apr 2012) of park.

A sample of 75 adult park

visits/week/park, and users were interviewed in each

1830 more MET-hours park at baseline and follow-up

of PA/week/park

Both residents and

park users in the

intervention arms

frequency of exercise.

No differences

between PD and PAB-

PD parks.

PA declined in control

parks 


\begin{tabular}{|c|c|c|c|}
\hline $\begin{array}{l}\text { One park was } \\
\text { part of an } \\
\text { initiative to } \\
\text { increase the } \\
\text { quality of } \\
\text { family and } \\
\text { youth-oriented } \\
\text { services and } \\
\text { programs }\end{array}$ & $\begin{array}{l}\text { used for soccer and } \\
\text { baseball } \\
\text { Including artificial } \\
\text { turf replaced uneven } \\
\text { dirt fields, new } \\
\text { fencing, landscaping, } \\
\text { lighting, and picnic } \\
\text { benches; new soccer } \\
\text { goals and walkway } \\
\text { around field; } \\
\text { programming; } \\
\text { training and skills } \\
\text { development for } \\
\text { park and recreation } \\
\text { program staff (total } \\
\text { cost } \$ 5.5 \mathrm{~m})\end{array}$ & $\begin{array}{l}\text { residents and } \\
\text { approximation in features } \\
\text { (e.g. presence of } \\
\text { playground, and } \\
\text { soccer/baseball area) }\end{array}$ & $\begin{array}{l}\text { increase in the average } \\
\text { number of visitors per } \\
\text { observation } \\
\text { For both genders, there } \\
\text { was a sig increase in } \\
\text { sedentary, moderate } \\
\text { activity and vigorous } \\
\text { activity visitors to the } \\
\text { intervention park } \\
\text { playfields } \\
\text { Sig increases in } \\
\text { number of visitors to } \\
\text { non-playfield areas }\end{array}$ \\
\hline
\end{tabular}

+ve, significant difference for park usage and/or PA levels in favor of intervention group versus control group; -ve, no significant difference for park usage and/or PA levels in favor of intervention group versus control group; MET, Metabolic equivalent; MVPA, moderate-vigorous physical activity; PA, physical activity; PAB, Park Advisory Board; PD, Park Directors; RCT, Randomized Controlled Trial; SD, standard deviation; sig, significant; SOPARC, Systems for Observing Play and Recreation in Communities; US, United States 
Table 2: Summary of Recommendations for Future Research

\begin{tabular}{|c|c|}
\hline Methodological Issue & Recommendation \\
\hline 1. Sample Size & Perform appropriate sample size calculation \\
\hline \multirow[t]{6}{*}{ 2. Outcome Measures } & Use objective measure of PA where possible \\
\hline & $\begin{array}{l}\text { Use domain specific and/or PA behavior specific measures (e.g., walking, } \\
\text { cycling) related to intervention }\end{array}$ \\
\hline & Include measures of purported mediators and moderators \\
\hline & $\begin{array}{l}\text { Incorporate analyses of mediators and moderators to assess direct and indirect } \\
\text { effects }\end{array}$ \\
\hline & Include triangulation of quantitative and qualitative data from multiple sources \\
\hline & $\begin{array}{l}\text { Use of complex conceptual and statistical models to account for cross-level } \\
\text { interactions of socio-ecological model }\end{array}$ \\
\hline \multirow[t]{3}{*}{ 3. Follow-up } & $\begin{array}{l}\text { Conduct follow-up at same time of year as baseline to control for seasonal } \\
\text { variation }\end{array}$ \\
\hline & Allow sufficient delay post-construction to ensure capture of "normal” usage \\
\hline & $\begin{array}{l}\text { Conduct a number of longer term follow-up assessments to account for } \\
\text { maintenance of behavior change and sustainability of UGS intervention }\end{array}$ \\
\hline \multirow[t]{3}{*}{ 4. Control Group } & $\begin{array}{l}\text { Use UGS of similar size and features, serving similar populations in terms of } \\
\text { socio-economic characteristics and have no planned changes during the study } \\
\text { period }\end{array}$ \\
\hline & Ensure geographically far enough apart to limit contamination \\
\hline & Informed by MRC guidelines for natural experiments (Craig et al, 2012) \\
\hline \multirow[t]{4}{*}{ 5. Target Population } & Need for studies outside of the US \\
\hline & Need for studies in low and middle income countries \\
\hline & $\begin{array}{l}\text { Need for studies investigating the influence of PA and UGS in children and } \\
\text { adolescents }\end{array}$ \\
\hline & $\begin{array}{l}\text { Evaluations should target populations living in target communities not only } \\
\text { park or trail users }\end{array}$ \\
\hline \multirow{2}{*}{$\begin{array}{l}\text { 6. Cost-effectiveness } \\
\text { Analysis }\end{array}$} & Include cost of maintenance of UGS in analyses \\
\hline & $\begin{array}{l}\text { Model wider impacts of health and society, for example, healthcare costs, } \\
\text { reduced carbon emissions, improvements in safety, less crime }\end{array}$ \\
\hline
\end{tabular}

\footnotetext{
7. Social Environment Potential influence of the social environment in association with the built environment should be considered in the design of future interventions
} 


\section{Appendix I: Search Strategy}

\section{Physical Activity}

1 (physical* adj activ*).ti, ab

2 exercise/ or exerc*.ti, ab

3 walking/ or walk*.ti, ab

4 (cycling or cycle or bike or biking or bicycle or bicycling). ti, ab

5 ((active adj travel*) or (active adj transport*) or (active adj commut*)). ti, ab

$6 \quad$ (active adj play*).ti, ab

7 (recreation* or leisure* or sport*). ti, ab

$8 \quad 1$ or 2 or 3 or 4 or 5 or 6 or 7

\section{Urban Green Space}

9 (urban adj green adj space). ti, ab

10 green*space. ti, ab

11 (open adj space). ti, ab

12 (public adj space). ti, ab

13 (public adj open adj space). ti, ab

14 (park not parkin*). ti, ab

15 ( city adj park). ti, ab

16 (public adj park). ti, ab

17 (urban adj park). ti, ab

18 (municipal adj park). ti, ab

19 (greenway or urban greenway). ti, ab

20 (urban adj regen*). ti, ab

21 (trail* or urban adj trail*). ti, ab

229 or 10 or 11 or 12 or 13 or 14 or 15 or 16 or 17 or 18 or 19 or 20 or 21

\section{Intervention}

23 intervention stud*.mp.

24 randomised control* trial.mp.

25 randomized control* trial.mp.

26 comparative stud*.mp.

27 control group.mp.

28 (randomised or randomized or randomly or groups).mp.

29 quasi*experiment*.mp.

30 natural experiment*.mp.

31 (pre test or pretest or pre intervention or post intervention or post test or posttest).mp.

32 (((control* or before or (before and after stud*) or follow up assessment).mp.

33 (intervention or interventional or process or program*).mp.

34 (evaluat* or intervention or interventional or treatment).mp.

3523 or 24 or 25 or 26 or 27 or 28 or 29 or 30 or 31 or 32 or 33 or 34

$36 \quad 8$ and 22 and 36

“ti, ab”, Title and Abstract; “adj”, Adjacent 


\section{Appendix II: Flow Diagram}

\section{IDENTIFICATION}

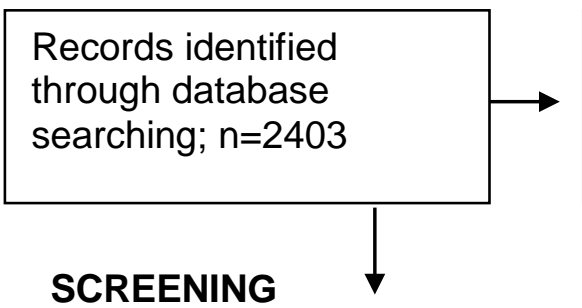

Additional records

identified through other

sources; $n=2$

\begin{tabular}{|c|c|}
\hline $\begin{array}{l}\text { Records screened } \\
N=2405\end{array}$ & $\begin{array}{l}\text { Records excluded } \\
N=2340\end{array}$ \\
\hline ELIGIBILITY & $\begin{array}{l}\text { Full-text articles excluded with } \\
\text { reasons; } n=53 \text { : }\end{array}$ \\
\hline $\begin{array}{l}\text { Full-text articles } \\
\text { assessed for eligibility; } \\
n=65\end{array}$ & $\begin{array}{l}N=22 \text { no measure of } P A \\
N=18 \text { not UGS-based intervention } \\
N=9 \text { no control group } \\
N=2 \text { study protocol } \\
N=2 \text { no full-text available }\end{array}$ \\
\hline
\end{tabular}

Studies included in qualitative synthesis; $n=12$ 


\section{Appendix III: Results of Risk of Bias Assessment}

\begin{tabular}{|c|c|c|c|c|c|c|c|c|c|}
\hline Reference & $\begin{array}{l}\text { Allocation } \\
\text { sequence }\end{array}$ & $\begin{array}{l}\text { Allocation } \\
\text { concealment }\end{array}$ & $\begin{array}{l}\text { Baseline } \\
\text { measurements }\end{array}$ & $\begin{array}{l}\text { Baseline } \\
\text { characteristics }\end{array}$ & $\begin{array}{l}\text { Incomplete } \\
\text { data }\end{array}$ & Blinding & Contamination & Reporting & Summary \\
\hline \multicolumn{10}{|c|}{ Changes to built environment only } \\
\hline Cohen et al, 2009a ${ }^{21}$ & No & No & Unclear & No & Unclear & No & Unclear & No & High \\
\hline Cohen et al, 2009b ${ }^{29}$ & No & No & No & No & Unclear & No & Unclear & Yes & High \\
\hline Fitzhugh et al, $2010^{23}$ & No & No & No & Yes & Unclear & No & Unclear & Yes & Unclear \\
\hline Branas et al, $2011^{19}$ & Yes & No & Unclear & Unclear & Unclear & No & Unclear & Yes & Unclear \\
\hline $\begin{array}{l}\text { West and Shores, } \\
2011^{30}\end{array}$ & No & No & No & No & Unclear & No & Unclear & Yes & High \\
\hline Cohen et al, $2012^{24}$ & No & No & No & Unclear & Unclear & No & Unclear & Yes & Unclear \\
\hline $\begin{array}{l}\text { Bohn-Goldbaum et al, } \\
2013^{26}\end{array}$ & No & No & No & No & Unclear & No & Unclear & Yes & High \\
\hline Cohen et al, $2014^{27}$ & No & No & Not applicable & Not applicable & Unclear & No & Unclear & Yes & Unclear \\
\hline \multicolumn{10}{|c|}{ Physical activity programming intervention only } \\
\hline Cohen et al, $2013^{20}$ & Yes & Unclear & Yes & Yes & Unclear & No & Unclear & Yes & Low \\
\hline \multicolumn{10}{|c|}{ Combination of built environment and physical activity programming intervention } \\
\hline Merom et al, $2003^{28}$ & No & No & No & No & Unclear & No & Unclear & Yes & High \\
\hline $\begin{array}{l}\text { Tester and Baker, } \\
2009^{22}\end{array}$ & No & No & No & Unclear & Unclear & No & Unclear & Yes & Unclear \\
\hline
\end{tabular}

Allocation sequence: Was the allocation sequence adequately generated?

Allocation concealment: Was allocation adequately concealed?

Baseline measurements: Were baseline outcome measurements similar?

Baseline characteristics: Were baseline characteristics similar?

Incomplete data: Were incomplete outcome data adequately addressed?

Blinding: Was knowledge of the allocated intervention adequately prevented during the study?

Contamination: Was the study adequately protected against contamination?

Selective reporting: Are reports of the study free of suggestion of selective outcome reporting? 